Authors: Remigiusz Knitter, Tomasz Królikowski

Title of article: „Metamateriały mechaniczne wytwarzane w sposób przyrostowy” (“Mechanical metamaterials manufactured by increasing technology")

Mechanik, Vol. 91, No. 7 (2018): pages 502-504

DOI: https://doi.org/10.17814/mechanik.2018.7.65

\title{
Mechanical metamaterials manufactured by increasing technology
}

\author{
Metamateriały mechaniczne wytwarzane \\ w sposób przyrostowy
}

\section{REMIGIUSZ KNITTER TOMASZ KRÓLIKOWSKI *}

\begin{abstract}
Presented is the first phase of work, which concerned the study of metamaterial mechanisms made of rubber-like plastics, and the impact of their structure and geometry on the transfer of a given force and displacement in a designed model, made using FDM (fused deposition modeling). The aim of the work is to examine the impact of technological parameters and changes in geometry and filling on the strength parameters of the manufactured object and further considerations on replacing the classic assemblies of mechanical elements with elements made using metamaterial structures.
\end{abstract}

KEYWORDS: 3D printers, additive technologies, metamaterial, mechanical metamaterial

Incremental techniques have been intensively developed since the early 1980s. They consist in the creation of layerby-layer elements, thanks to which it is possible to obtain objects with a complicated internal structure or gradient materials with variable material parameters.

Initially, incremental production was useful for the preparation of unit prototypes. With time, along with the development of various incremental manufacturing techniques, it has become possible to use in them typical materials from which everyday objects such as ABS, biodegradable PLGA and PLLA are manufactured (they can be used, for example, stents for use) medical) and metal (for the production of aircraft and even rocket engine components).

Described method shows the stages of designing metamaterials, including modeling reflecting the geometry and selection of optimal parameters (strength, functionality). In connection with the 4.0 industrial revolution, advanced methods of designing and producing details, often individual or short production series, are sought for.

In recent scientific publications [10], new constructions are described in which not only shapes but also their internal microstructure play an important role. Such objects, usually based on three-dimensional networks, are also known as metamaterials and can be used to create materials with soft and hard regions.

\footnotetext{
* Mgr inż. Remigiusz Knitter (remigiusz.knitter@tu.koszalin.pl), prof nadzw. dr hab. inż. Tomasz Królikowski (tomasz.krolikowsk @tu.koszalin.pl) - Katedra Mechatroniki i Mechaniki Stosowanej, Wydział Technologii i Edukacji Politechniki Koszalińskiej
}

Metamaterial mechanisms consist of a single block of material whose cells interact with each other in a precisely defined way to obtain a designed macroscopic motion. The key element here is the specialized cell type, the character of which is determined by shear capacity. Metamaterials are artificial structures, usually with repeating patterns of internal junction nodes. Unusual properties owe their geometry to the material they are made of. Metamaterial structures have been optimized by algorithms defining the programmed direction of motion, taking into account the results of experimental research.

The development of mechanical metamaterials is favored by advances in the incremental method, in other words 3D printing with high resolution. An example of this is the printed Bickel material with pores that lower its resistance to even compression, i.e. overall stiffness.
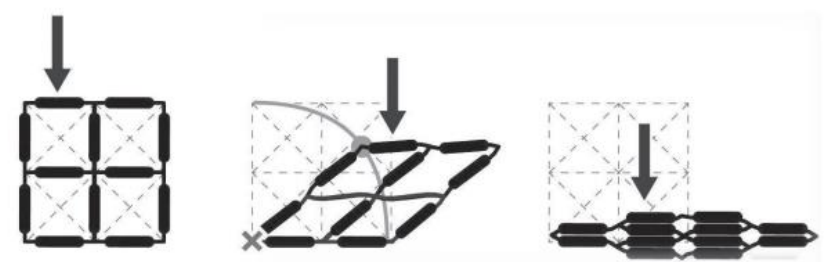

Fig. 1. Behavior of a square metamaterial cell due to force application [9]

Typical mechanical metamaterials are characterized by four constants: the Young $E$ module, the Kirchoff $G$ module, the mass module $K$ and the Poisson ratio $v$. The first three of them are responsible for the stiffness and compressibility of material from the engineering point of view. At this stage, the results of optimization of structural topology are used, using the basic design principles, in combination with experimental studies, in order to obtain various mechanical properties that are counter-intuitive [1-3, 6].

The paper presents a designed metamaterial with actively controlled mechanical properties. The metamaterial has a deformable structure and activating elements that can be controlled and computer simulated using the finite element method. In one aspect, it resembles a composite in which the communication between the constituent materials or the shape and arrangement of the constituent materials is dynamically controlled so as to affect the mechanical properties of the metamaterial. 
Composites can also be multifunctional materials, minimize size and weight, both as controlled mechanical components and as supporting structures. One of such multifunctional applications is intelligent or circular leather, which has a protective, adaptive and functional function (eg absorbs energy).

The presented research constitutes the initial stage of work on the durability of components printed on spatial printers in various technologies. At this stage, the FDM (fused deposition modeling) method was used.

The paper presents the results of tests on tensile strength of samples printed from a Fiberflex 40D rubber material (Fiberlogy) on a 3D printer (Blixet B24), with suitably selected parameters for material and printer.

The basic material data provided by producers and distributors of materials used in the FDM method, such as tensile strength and Young's modulus, refer to the most favorable model setting during printing. However, the object manufactured with incremental technology, and especially with the FDM method, is very strongly diversified (in the direction of the $Z$ axis). The direction of material application is also important (in the $X Y$ plane) [5]. The durability and type of filling the interior of the model as well as the temperature during printing also affect durability. For these reasons, in the case of specific materials, it is necessary to recognize the relationship between technological parameters and the obtained strength.

Metamaterials are composite structures designed and manufactured by humans, not found in nature. They exhibit new, unusual properties, determined primarily by the morphology of the structure, and to a lesser extent by the chemical / phase composition. A special case of metamaterials are nano-hetero-structures [9].

\section{Construction of metamaterial structures}

The construction of structures depends on their intended use. All structures should be of the same size and geometry, set in such a way that they perform specific tasks in the simulation using the finite element method.

During the initial tests, an element was considered to replace a spring in which there is a linear dependence of the elastic force $F$ on the spring deflection from the equilibrium position $x$.

$$
F=-k x
$$

where: $k$ - coefficient of elasticity (spring constant), determines the increase in force with the deflection of the spring.

Then the energy accumulated in the deformed spring is:

$$
E_{\mathrm{p}}=\frac{1}{2} k x^{2}
$$
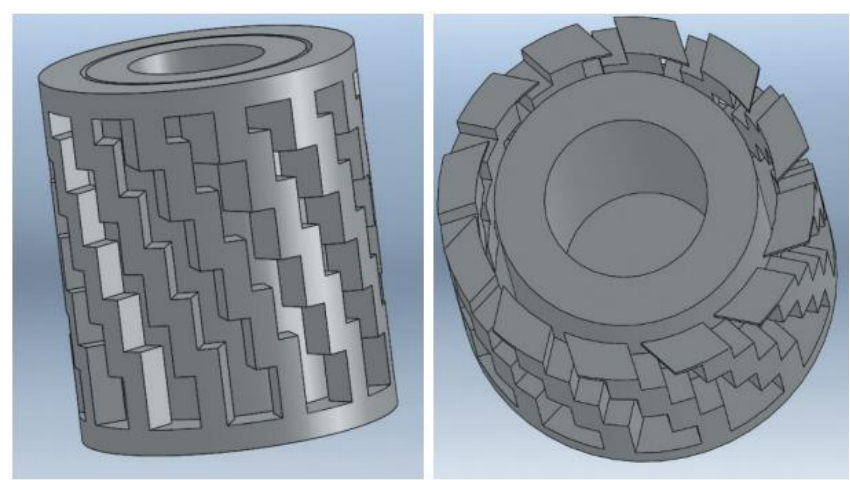

Fig. 2. Tested element modeled in a 3D CAD environment
The modeled structure was printed on a FDM Blixet B24 3D printer made of Fiberlogy Fiberflex 40D material, which has an elongation of $680 \%$. The filament shows high impact strength even at low temperature (even at $-40^{\circ} \mathrm{C}$ ). It is also very thermally resistant (up to $70^{\circ} \mathrm{C}$ ), chemically and abrasion.

TABLE. Print parameters of the tested element using the FDM method

\begin{tabular}{|c|c|}
\hline Printer & FDM BLIXET B24-Multi \\
\hline Head temperature & $210^{\circ} \mathrm{C}$ \\
\hline Table temperature & $45^{\circ} \mathrm{C}$ \\
\hline Material feeding speed & $20 \mathrm{~mm} / \mathrm{s}$ \\
\hline Colling (fan rotations) & $\begin{array}{c}\text { First layer: } 20 \% \\
\text { Subsequent layers: } 40 \%\end{array}$ \\
\hline Nozzle diameter & $0,4 \mathrm{~mm}$ \\
\hline Filament & Fiberlogy Fiberflex $40 \mathrm{D}$ czarny \\
\hline Filament diameter & $1,75 \mathrm{~mm}$ \\
\hline Layer height & $0,2 \mathrm{~mm}$ \\
\hline Filling type & Cross $45^{\circ}$ \\
\hline Filling & Full $( \pm 100 \%)$ \\
\hline
\end{tabular}

\section{Simulation using the finite element method}

The computer simulation using the finite element method was carried out in the ANSYS program. The element was to deform at given limits of elasticity.

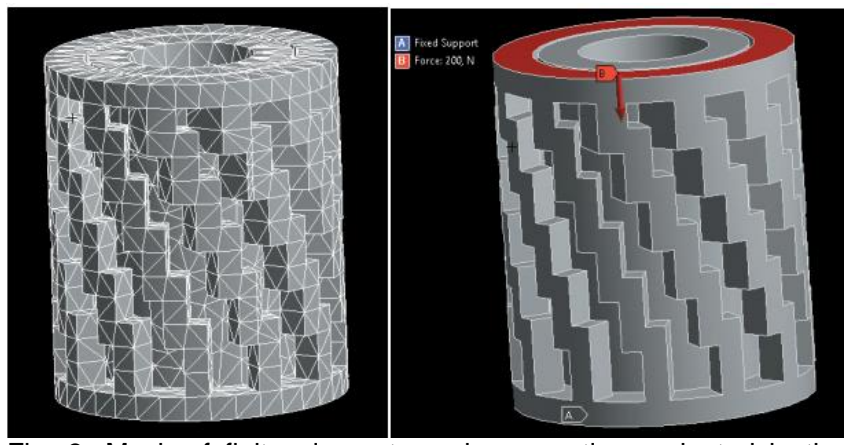

Fig. 3. Mesh of finite elements and assumptions adopted in the ANSYS program (force $200 \mathrm{~N}$, established basis of geometry)

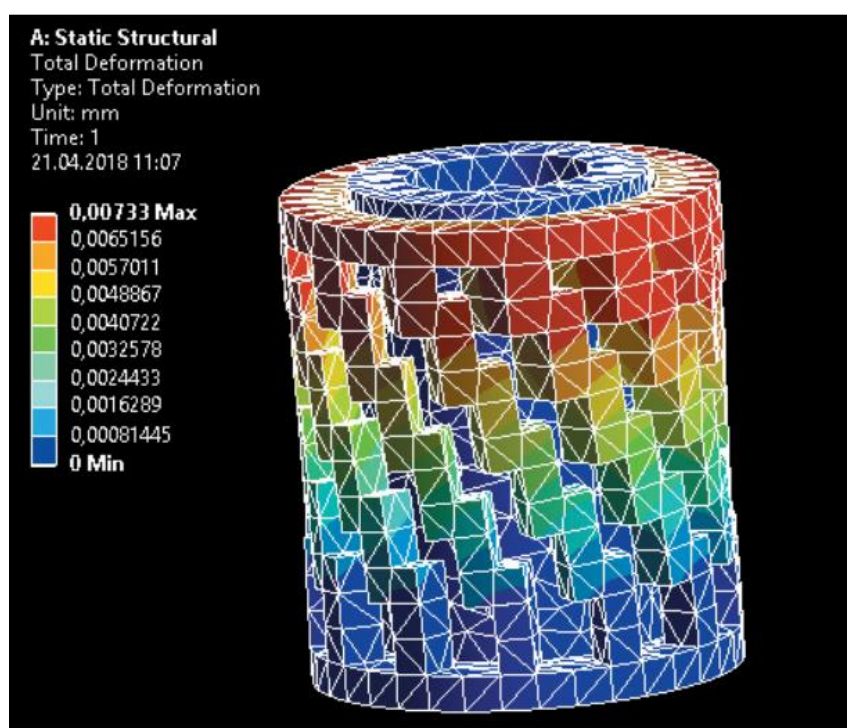

Fig. 4. Results of the deformation of the examined element in computational calculations 


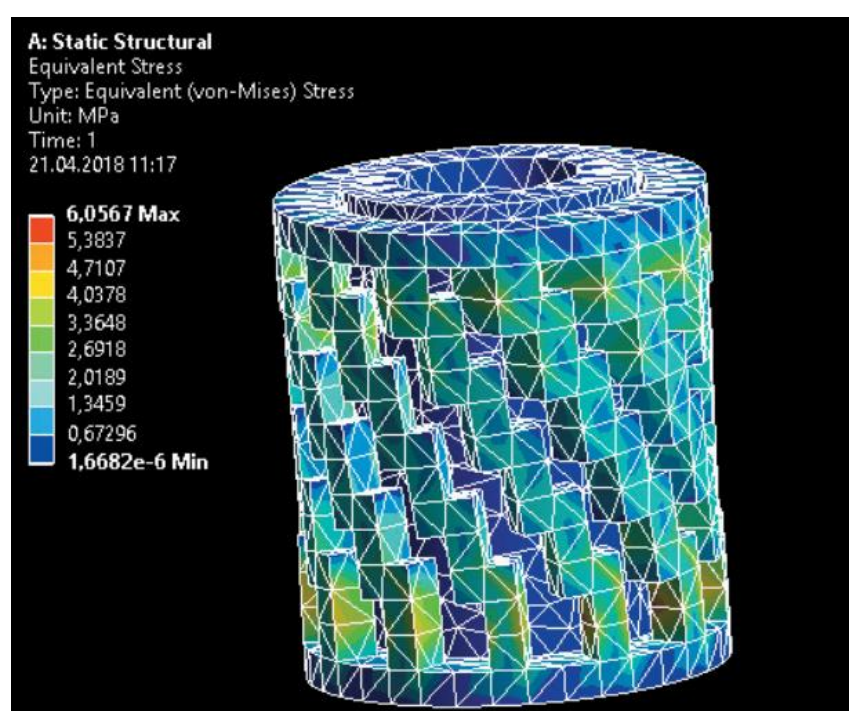

Fig. 5. Chart of Hubert-Mises reduced stress of the tested element
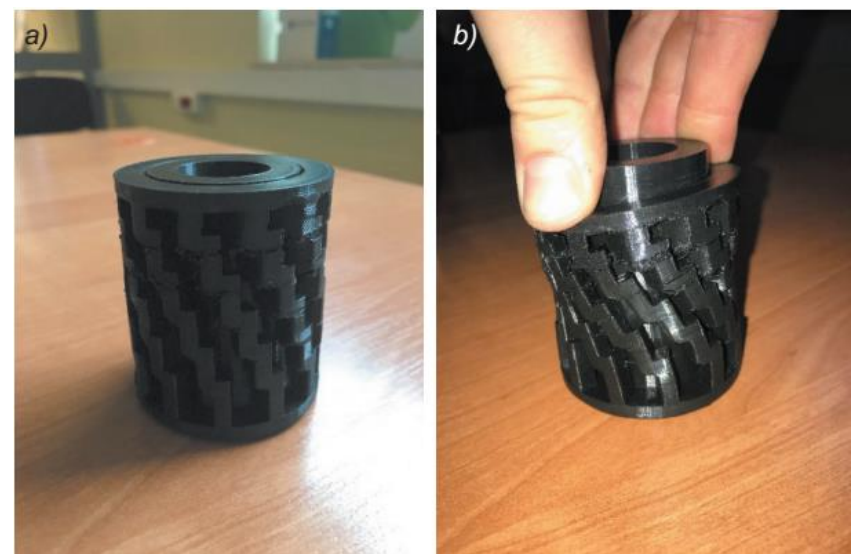

Fig. 6. Spring with a guide using metamaterial cells, made by the FDM method: a) before application of force, $b$ ) after applying force

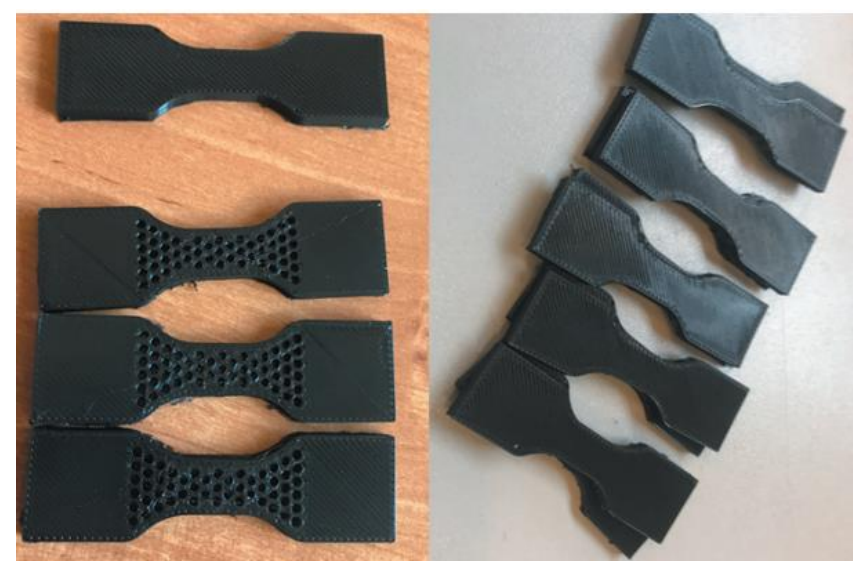

Fig. 7. Samples prepared for testing

\section{Further planned research stage}

Initial tests showed very high flexibility of the structure, going beyond the scope of the measuring equipment (no possibility of breaking the sample with the modeled structure). Further activities are aimed at developing a methodology for designing structures that allow obtaining desired mechanical properties; they also assume experimental research of designed mechanisms.

The fittings were modeled in the Solid Works program, in accordance with ISO 3167 and ISO 294 [6, 7].

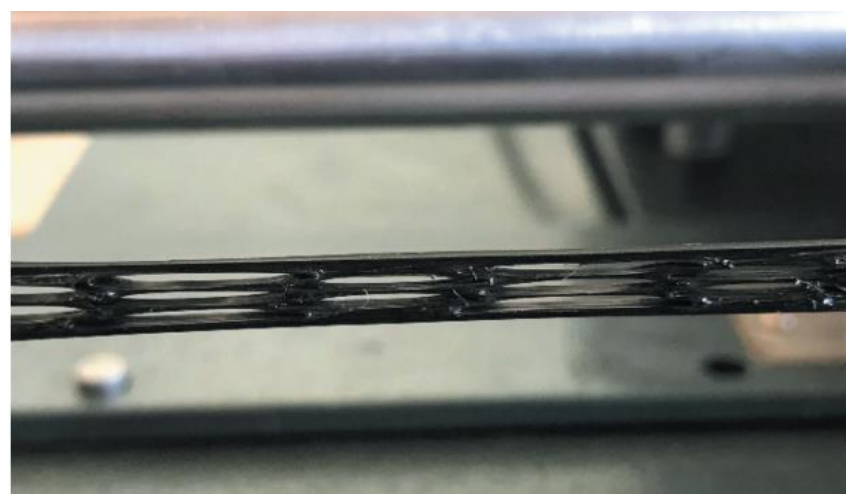

Fig. 8. Structure of a stretched sample during preliminary tests

\section{REFERENCES}

1. Dziewit P., Janiszewski J. „Ocena jakościowa procesu deformacji regularnych struktur komórkowych wykonanych techniką druku 3D". Mechanik. 3 (2018): s. 250-252.

2. Kinsler P., McCall W. „The futures of transformations and metamaterials". Blackett Laboratory, Imperial College London, Prince Consort Road, London SW7 2AZ, United Kingdom.

3. Kret M. „Drukarki 3D - porównanie”. Mechanik. 11 (2010): s. 864-866 (polskie opracowanie na podstawie T. A. Grimm \& Associates, Inc: 3D Printer Benchmark - North American Edition. www.tagrimm.com/benchmark-2010).

4. Madej J., Śliwka M. „Badanie parametrów mechanicznych struktur drukowanych o różnym zagęszczeniu". Mechanik. 11 (2017): s. 1072-1074

5. Miazio $Ł$. „Badanie wytrzymałości na rozciąganie próbek wydrukowanych w technologii FDM z różną gęstością wypełnienia". Mechanik. 7 (2015): s. 533-538.

6. Norma PN-EN ISO 527... - Oznaczanie właściwości mechanicznych przy statycznym rozciąganiu.

7. Normy ISO 3167 , ISO 294 - dotyczące wykonywania i geometrii kształtek z tworzyw termoplastycznych stosowanych do badań.

8. Novakova-Marcincinova L., Novak-Marcincin J. „Testing of materials for rapid prototyping fused deposition modelling technology". World Academy of Science. Engineering and Technology. 70 (2012).

9. Schumacher C., Bickel B., Rys J., Marschner S., Daraio C., Gross M. "Microstructures to control elasticity in 3D printing". ACM Transactions on Graphics. 34, 4 (2015).

10. Vinay H. Ba, Govindarajub H.K., Prashanth Banakarc. AMMMT 2016 Experimental Study on Mechanical Properties of Polymer Based Hybrid Composite Materials Today": Proceedings. 4 (2017): s. 10904-10912.

Translation of scientific articles, their computer composition and publishing them on the website www.mechanik.media.pl by original articles in Polish is a task financed from the funds of the Ministry of Science and Higher Education designated for dissemination of science.

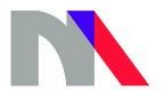

Ministry of Science and Higher Education Republic of Poland 